\title{
A lightning climatology of the South-West Indian Ocean
}

\author{
C. Bovalo, C. Barthe, and N. Bègue \\ Laboratoire de l'Atmosphère et des Cyclones, UMR8105, CNRS/INSU - Météo France and Université de La Réunion, \\ Saint-Denis, La Réunion, France \\ Correspondence to: C. Bovalo (christophe.bovalo@meteo.fr)
}

Received: 30 March 2012 - Revised: 22 June 2012 - Accepted: 29 July 2012 - Published: 22 August 2012

\begin{abstract}
The World Wide Lightning Location Network (WWLLN) data have been used to perform a lightning climatology in the South-West Indian Ocean (SWIO) region from 2005 to 2011. Maxima of lightning activity were found in the Maritime Continent and southwest of Sri Lanka $\left(>50 \mathrm{fl} \mathrm{km}^{-2} \mathrm{yr}^{-1}\right.$ ) but also over Madagascar and above the Great Lakes of East Africa $\left(>10-20 \mathrm{fl} \mathrm{km}^{-2} \mathrm{yr}^{-1}\right.$ ). Lightning flashes within tropical storms and tropical cyclones represent $50 \%$ to $100 \%$ of the total lightning activity in some oceanic areas of the SWIO (between $10^{\circ} \mathrm{S}$ and $20^{\circ} \mathrm{S}$ ).

The SWIO is characterized by a wet season (November to April) and a dry season (May to October). As one could expect, lightning activity is more intense during the wet season as the Inter Tropical Convergence Zone (ITCZ) is present over all the basin. Flash density is higher over land in November-December-January with values reaching $3-4 \mathrm{fl} \mathrm{km}^{-2} \mathrm{yr}^{-1}$ over Madagascar. During the dry season, lightning activity is quite rare between $10^{\circ} \mathrm{S}$ and $25^{\circ} \mathrm{S}$. The Mascarene anticyclone has more influence on the SWIO resulting in shallower convection. Lightning activity is concentrated over ocean, east of South Africa and Madagascar.

A statistical analysis has shown that El Niño-Southern Oscillation mainly modulates the lightning activity up to $56.8 \%$ in the SWIO. The Indian Ocean Dipole has a significant contribution since $\sim 49 \%$ of the variability is explained by this forcing in some regions. The Madden-Julian Oscillation did not show significative impact on the lightning activity in our study.
\end{abstract}

\section{Introduction}

The World Meteorological Organization (WMO) has long been the only available source of information about thunderstorm days (World Meteorological Organization, 1953).
Lightning activity was recorded by human observers based on the sound of thunder. This kind of data is very sparse and may not be representative of a specific region. A better knowledge of location and frequency of global and regional lightning activity has been possible with the emergence of ground-based detection networks and satellite observations.

A global lightning climatology, based on a 5-yr dataset, has been proposed by Christian et al. (2003) using the Optical Transient Detector (OTD) on-board the MicroLab-1 satellite. Flash rate extrema were found in coastal regions (Gulf of Mexico, Florida or Indonesian Archipelago), mountainous regions (Himalayas, Andes of northern Colombia) and convergence zones (South Pacific Convergence Zone or Inter Tropical Convergence Zone (ITCZ)). However, the highest flash rate $\left(82.7 \mathrm{fl} \mathrm{km}^{-2} \mathrm{yr}^{-1}\right)$ was obtained in the equatorial Congo Basin. Lightning Imager Sensor (LIS) data were used by Collier et al. (2006) to study the seasonal and diurnal variations of lightning activity over southern Africa. As in Christian et al. (2003), the highest flash density was found in the Congo Basin $\left(107 \mathrm{fl} \mathrm{km}^{-2} \mathrm{yr}^{-1}\right)$, but Madagascar and South Africa also exhibit high flash density $\left(32.1 \mathrm{fl} \mathrm{km}^{-2} \mathrm{yr}^{-1}\right.$ and $26.4 \mathrm{fl} \mathrm{km}^{-2} \mathrm{yr}^{-1}$, respectively). It is also important to note that the flash density reported by Collier et al. (2006) is higher than in Christian et al. (2003) due to a higher detection efficiency with LIS compared to OTD (see Fig. 3 of Christian et al., 2003).

Regional lightning climatologies are also available and mainly based on national lightning detection networks. They have been used to estimate thunderstorm duration (Reap and Orville, 1990) and to understand how local geography can affect lightning distribution (Hodanish et al., 1997; Antonescu and Burcea, 2010). Reap and Orville (1990) proposed a cloud-to-ground lightning climatology over the United States for the period 1989-1996 based on a dataset provided by the National Lightning Detection Network (NLDN). They 
showed that the maximum flash density occurs mainly over the south-east $\left(>7 \mathrm{fl} \mathrm{km}^{-2} \mathrm{yr}^{-1}\right)$ and especially over Florida $\left(>11 \mathrm{fl} \mathrm{km}^{-2} \mathrm{yr}^{-1}\right)$, whereas Appalachian Mountains exhibit the lowest flash density. Hodanish et al. (1997) studied more specifically the Florida region using the same network for the period 1986-1995 and showed that the location of lightning flashes strongly depends on synoptic and mesoscale conditions. Sea and lake breezes and flow-topography interactions are found to trigger convection, and thus thunderstorms. However, mesoscale frontal systems are also a major source of lightning flashes. In Europe, Antonescu and Burcea (2010) studied the cloud-to-ground lightning activity over Romania using the Romanian Lightning Detection Network data from 2003 to 2005 and 2007. They found that high flash density is mainly associated with high topography with the maximum value ( $>3.06 \mathrm{fl} \mathrm{km}^{-2} \mathrm{yr}^{-1}$ ) over the Carpathian Mountains. Other climatologies used national detection networks in Austria (Schulz et al., 2005), in Spain (Rivas Soriano et al., 2005) and in Australia (Kuleshov et al., 2006).

However, national lightning detection networks have some limitations. For example, lightning activity over open ocean can not be studied with this kind of network. Moreover, only a few countries owns this kind of system. For some applications, a global network such as the World Wide Lightning Location Network (WWLLN) is better suited. Recently, Kucieńska et al. (2010) proposed a climatology over Mexico and adjacent oceanic regions using the WWLLN dataset, composed of $5 \mathrm{yr}$ of records (2005-2009). As in Antonescu and Burcea (2010), they found that thunderstorms with high flash density are the results of orography forcing, but sustained lightning activity also occurs in low altitude areas. Coastal clouds were found to act like continental clouds as they produced a large amount of lightning. Oceanic regions such as Caribbean Sea or Gulf of Mexico showed high flash density, whereas the lowest lightning activity was found in the subtropical Pacific. Indeed, as suggested by Zhang (1993), deep convection develops above warm water with sea surface temperature $>26^{\circ} \mathrm{C}$. The WWLLN data are then well suited to study lightning activity over the open ocean. In particular, several studies by Price et al. (2009), Thomas et al. (2010) and Abarca et al. (2011) investigated the relationships between lightning activity and tropical cyclone (TC) intensity for systems near land and in the open ocean using WWLLN data.

Up to now, the lightning activity in the South-West Indian Ocean (SWIO) has not been investigated. However, this basin has shown interesting electrical phenomena such as transient luminous events (TLEs) which occurs in the middle and upper atmosphere. Wescott et al. (2001) presented a photograph of a blue jet which developed north of La Réunion (a French island in the Indian Ocean) which shows some details of streamers never observed before. More recently, Soula et al. (2011) recorded 5 gigantic jets in an isolated storm near La Réunion at about $50 \mathrm{~km}$ from the observation site.
The Indian Ocean is also known to be affected by different modes of variability such as El Niño-Southern Oscillation (ENSO; Alexander et al., 2002; Tourre and White, 2003; Timm et al., 2005), the Madden-Julian Oscillation (MJO ; Zhang, 2005), the Quasi-Biennal Oscillation (QBO; Tourre and White, 2003) and the Indian Ocean Dipole (IOD; Saji et al., 1999; Morioka et al., 2010), which can affect deep convection and consequently lightning activity.

The main purpose of this work is to propose the first lightning climatology in the South-West Indian Ocean. This study also tries to better understand the mechanisms and the variability associated with lightning activity in this region. The paper is organized as follows: Sect. 2 presents the data and methodology, and Sect. 3 describes the lightning activity in the SWIO and its variability.

\section{Data and methodology}

Our interest area is the SWIO, which we define as the region geographically bounded by $10^{\circ} \mathrm{N}-50^{\circ} \mathrm{S}$ and $30^{\circ} \mathrm{E}-110^{\circ} \mathrm{E}$. This choice was made firstly to capture the change in position of the ITCZ which causes the different monsoon regimes in this ocean, and secondly to encompass all the possible cyclone trajectories tracked by the Regional Specialized Meteorological Centre (RSMC) at La Réunion.

\subsection{Lightning data}

Lightning data from 2005 to 2011 are extracted from the WWLLN database. The WWLLN (http://www.wwlln.net/) is a real-time lightning detection network with global coverage. In 2006, 28 stations recorded lightning strokes. Their number increased to 30 in 2007 , and currently the network is composed of 54 sensors detecting sferic (impulsive signal from lightning discharges) activity. The WWLLN uses the "time of group arrival" of very low frequency radiation $(3-30 \mathrm{kHz})$ to locate lightning strokes. According to the developers, a stroke has to be detected by at least 5 stations to have a good location accuracy. Due to its global coverage, the WWLLN has been used to study TCs (Solorzano et al., 2008; Price et al., 2009; DeMaria et al., 2012), lightningproduced $\mathrm{NO}_{\mathrm{x}}$ (Beirle et al., 2010; Bucsela et al., 2001) and TLEs (Soula et al., 2011).

This network detects both cloud-to-ground (CG) and intracloud (IC) lightning, but as CGs have higher peak current, their detection efficiency (DE) is about twice the IC DE. Abarca et al. (2010) compared the CG flash density between the WWLLN and the NLDN which has a higher DE in its coverage area (continental US and adjacent waters). They showed that the WWLLN DE increased from $3.88 \%$ in 2006 to $10.30 \%$ in 2010 and is dependant of the peak current. Even if the NLDN detects 10 times more flashes, the WWLLN can well capture the lightning activity as the spatial correlation between the NLDN and the WWLLN recorded 
Table 1. WWLLN detection efficiency obtained using the LIS/OTD data as ground truth.

\begin{tabular}{cc}
\hline Year & $\begin{array}{c}\text { WWLLN detection } \\
\text { efficiency (in \%) }\end{array}$ \\
\hline 2005 & 2.0 \\
2006 & 3.4 \\
2007 & 5.0 \\
2008 & 4.7 \\
2009 & 6.6 \\
2010 & 8.3 \\
2011 & 8.5 \\
\hline
\end{tabular}

flashes reached a value of 0.75 in 2008/2009. Rodger et al. (2009) showed that the location accuracy has globally a spatial dependence (between 10 and $20 \mathrm{~km}$ in the SWIO: see their Fig. 5). Abarca et al. (2010) found that, for the US region, the WWLLN has a northward and a westward bias of about $4.03 \mathrm{~km}$ and $4.98 \mathrm{~km}$, respectively. Soula et al. (2011) showed that the lightning strokes detected by the WWLLN in an isolated thunderstorm near La Réunion $\left(21^{\circ} \mathrm{S} ; 55.5^{\circ} \mathrm{E}\right)$ in March 2010 coincided with the lowest cloud top temperature. The lightning flashes were also recorded by a video camera and the same trend was obtained using the recorded data and the WWLLN data.

As explained above, the WWLLN DE is quite low even if the increase in the number of stations has increased the DE. In order to scale up the results obtained with the WWLLN data, the annual mean lightning density from the LIS/OTD (horizontal resolution of $0.5^{\circ}$ ) is used as ground truth. The LIS and OTD properties are described by Boccippio et al. (2002). The protocol is the same as DeMaria et al. (2012); for each year of the study, the ratio between the annual average flash density over the SWIO and the average LIS/OTD climatology over the same domain (i.e. the DE) has been calculated. Thus, the WWLLN data were multiplied by a calibration factor which is the inverse of the DE. Table 1 shows the evolution of the WWLLN lightning detection rate; in the SWIO, the DE was about $2.04 \%$ in 2005 and increased up to about $8.5 \%$ in 2011. These DEs are quite similar to those of Abarca et al. (2010) but differ from those of DeMaria et al. (2012) since 2009; the DEs found by DeMaria et al. (2012) reach up to $20 \%$. These differences may be explained by the fraction of land-sea or the station distribution.

As the WWLLN location accuracy is $10-20 \mathrm{~km}$ in the SWIO (Rodger et al., 2009), we performed our climatology at a $0.5^{\circ}$ resolution. This resolution is high enough since small scale features are not investigated herein.

\subsection{Variability}

Convection in the Indian Ocean is known to be affected by different modes of variability such as ENSO, MJO, QBO or IOD. Indeed, the IOD and ENSO are coupled ocean-atmosphere phenomena leading to warmer or cooler sea surface temperatures (SST) which affect convection (Zhang, 1993). The QBO also modulates convection which is damped (enhanced) during the west (east) phase (Collimore et al., 2003).

To identify the impact of the different modes of variability affecting the SWIO on the lightning activity, we used a statistical model called "Trend-Run" (Bencherif et al., 2006; Bègue et al., 2010). Previously, temperature trends and variations over 2 subtropical sites (Durban and La Réunion) have been studied with this model using monthly mean radiosonde temperature profiles (for the periods 1980-2001 and 19932008, respectively).

Trend-Run is a linear regression fitting model based on a multivariate least squares method that initially includes terms for the Annual Cycle (AC), the Semi-Annual Cycle (SAC), the QBO, the ENSO and the 11-yr solar cycle (using the Sun Spot Number (SSN)). The variations of a time series $Y(t)$ are broken down into the sum of the previous parameters:

$$
\begin{aligned}
Y(t)= & c_{1} \mathrm{SAC}(t)+c_{2} \mathrm{AC}(t)+c_{3} \mathrm{QBO}(t) \\
& +c_{4} \operatorname{ENSO}(t)+c_{5} \operatorname{SSN}(t)+\epsilon(t),
\end{aligned}
$$

where $\epsilon(t)$ is the residual term.

Recent results by Morioka et al. (2010) revealed that IOD acts as a major climate mode in the SWIO. Thus, the IOD has been included (Bègue et al., 2010) using the Dipole Mode Index (Behera and Yamagata, 2003) defined as the difference in SST between the western and eastern tropical Indian Ocean. Since the MJO is the dominant intra-seasonal mode of variability in the tropics (Zhang, 2005), this forcing has also been added in Trend-Run. We used the index of Wheeler and Hendon (2004) which is based on the first two empirical orthogonal functions of combined fields of $850 \mathrm{hPa}$ zonal wind, $200 \mathrm{hPa}$ zonal wind and outgoing longwave radiation (near the equator and averaged). In its final form, Trend-Run decomposes a geophysical signal $Y(t)$ as follows:

$$
\begin{aligned}
Y(t)= & c_{1} \mathrm{SAC}(t)+c_{2} \mathrm{AC}(t)+c_{3} \mathrm{QBO}(t) \\
& +c_{4} \operatorname{ENSO}(t)+c_{5} \operatorname{SSN}(t) \\
& +c_{6} \operatorname{IOD}(t)+c_{7} \operatorname{MJO}(t)+\epsilon(t) .
\end{aligned}
$$

More details on Trend-Run are available in Bencherif et al. (2006) and Bègue et al. (2010).

In order to investigate the lightning activity variability in the SWIO, the initial area was subdivided into $10^{\circ} \times 10^{\circ}$ bins, and the WWLLN strokes were counted to get monthly time series for each box. Due to the limited index time series, our period of study only covers March 2005 to July 2010. In order to focus on the tropical forcings, we also restricted our study area to the $0^{\circ}-30^{\circ} \mathrm{S}$ belt. 


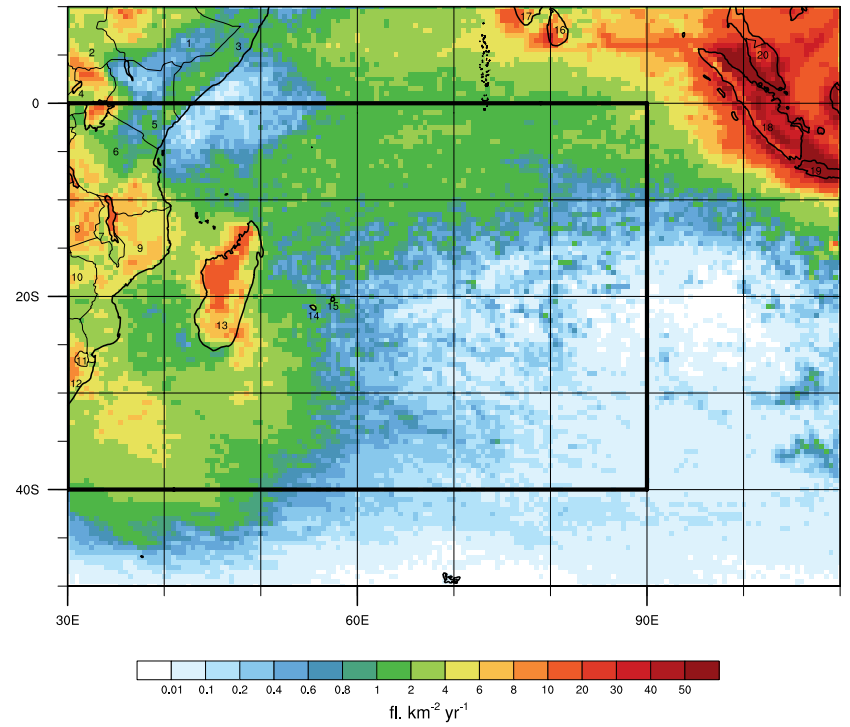

Fig. 1. Distribution of the annual mean flash density $\left(\mathrm{fl} \mathrm{km}^{-2} \mathrm{yr}^{-1}\right)$ over the SWIO. The black box corresponds to the area of responsibility of RSMC La Réunion. The different numbers stand for the country or region: 1-Ethiopia, 2-Sudan, 3-Somalia, 4-Uganda, 5-Kenya, 6-Tanzania, 7-Malawi, 8-Zambia, 9-Mozambique, 10Zimbabwe, 11-Swaziland, 12-South Africa, 13-Madagascar, 14-La Réunion, 15-Mauritius, 16-Sri Lanka, 17-India, 18-Sumatra, 19Java and 20-Malaysia.

\section{Lightning activity in the SWIO region}

\subsection{Spatial distribution}

The annual mean flash density over the SWIO is shown in Fig. 1. The lightning distribution over this region follows the main features of the 1995-2005 climatology developed by Christian et al. (2003) from OTD: the "hot spots" in the SWIO are found in Indonesia, Sri Lanka, South India and Madagascar. Moreover, the lightning activity in the Mozambique channel is quite similar in trend.

In the study area, the more electrically active regions are the Maritime Continent (especially Java island) and the southwest of Sri Lanka with more than $50 \mathrm{fl} \mathrm{km}^{-2} \mathrm{yr}^{-1}$. It is worth noting that the strait of Malacca exhibits the second highest flash density. Fujita et al. (2010) suggested that gravity currents generated by precipitation over the eastern and western coastal area of Sumatra and Malay Peninsula can converge and trigger convection over the strait. Teo et al. (2011) proposed that the strait of Malacca can be seen as a wave cavity. Lake Malawi $\left(12.2^{\circ} \mathrm{S} ; 34.4^{\circ} \mathrm{E}\right)$ and Lake Victoria $\left(1.0^{\circ} \mathrm{S}\right.$; $\left.33.1^{\circ} \mathrm{E}\right)$ also exhibit high flash densities, higher than $8 \mathrm{fl} \mathrm{km}^{-2} \mathrm{yr}^{-1}$. During the day, downdraft and dry air are present above these lakes, whereas convergence is associated with precipitation during the night. Convective instability is enhanced due to an increase of evaporation above lakes which is a source of water vapor to the prevailing systems. Concerning Madagascar, lightning flashes are preferentially triggered over the low highlands and plains in the northwestern and western parts of the country $\left(10-20 \mathrm{fl} \mathrm{km}^{-2} \mathrm{yr}^{-1}\right)$. The flash density is between 2 and $8 \mathrm{fl} \mathrm{km}^{-2} \mathrm{yr}^{-1}$ in the southern and eastern parts of the island.

In the southwestern part of the SWIO $\left(30^{\circ} \mathrm{S}-45^{\circ} \mathrm{S}, 30^{\circ} \mathrm{E}-\right.$ $\left.50^{\circ} \mathrm{E}\right)$, the significant lightning activity $\left(4-8 \mathrm{fl} \mathrm{km}^{-2} \mathrm{yr}^{-1}\right)$ could be caused by cold fronts and mid-latitudes storms.

Figure 1 also illustrates the land-ocean contrast in lightning activity with associated deep convection stronger over land than over ocean. Apart from the African continent, the islands of Madagascar, Java and Sri Lanka have the highest flash densities, in agreement with Williams and Stanfill (2002). They examined the annual thunder day counts for all islands included in the WMO worldwide compilation and concluded that the larger islands are associated with the higher annual number of thunder days.

In the SWIO, some areas exhibit very low or almost null lightning density. The region $20^{\circ} \mathrm{S}-50^{\circ} \mathrm{S}, 70^{\circ} \mathrm{E}-110^{\circ} \mathrm{E}$ shows a gap in lightning activity that can be explained partly by the presence of the Mascarene anticyclone. Two other areas of low flash density $\left(<2 \mathrm{fl} \mathrm{km}^{-2} \mathrm{yr}^{-1}\right)$ are located south of the Mozambique channel and near Somalia shores. This may be caused by the presence of subsiding air from the Walker circulation and the Hadley cell. Lau and Yang (2003) proposed an annual mean position of the different ascending and descending branches of the Walker circulation using the NCEP-NCAR (National Centers for Environmental Prediction - National Center for Atmospheric Research) reanalysis for the period 1949-1999. They showed that in the Indian Ocean near East African coasts there is a narrow region of subsidence with maximum descent in the upper troposphere. Concerning the Mozambique channel area, the region of subsidence may be caused by the Hadley cell.

\subsection{Impact of tropical storms and cyclones on lightning activity}

In most tropical basins, deep convection can be separated into tropical cyclones and local convection. In the SWIO, the TC activity represents $10-12 \%$ of the global total annual TC activity (Neumann, 1993) with a dozen depressions observed on average per season. More than 9 of these depressions reach the stage of moderate tropical storms (TSs), of which half become TCs (Caroff et al., 2008). As highlighted by more and more studies, tropical cyclones exhibit specific lightning activity (Black and Hallet, 1999; Squires and Businger, 2008; Price et al., 2009; Abarca et al., 2010; Fierro et al., 2011; DeMaria et al., 2012, among others).

Here, we focus on the impact of the tropical storms on the lightning climatology of the SWIO, and we try to quantify the proportion of lightning associated with TSs and TCs. Information concerning the tropical cyclone positions (latitude and longitude) is obtained from the RSMC La Réunion 


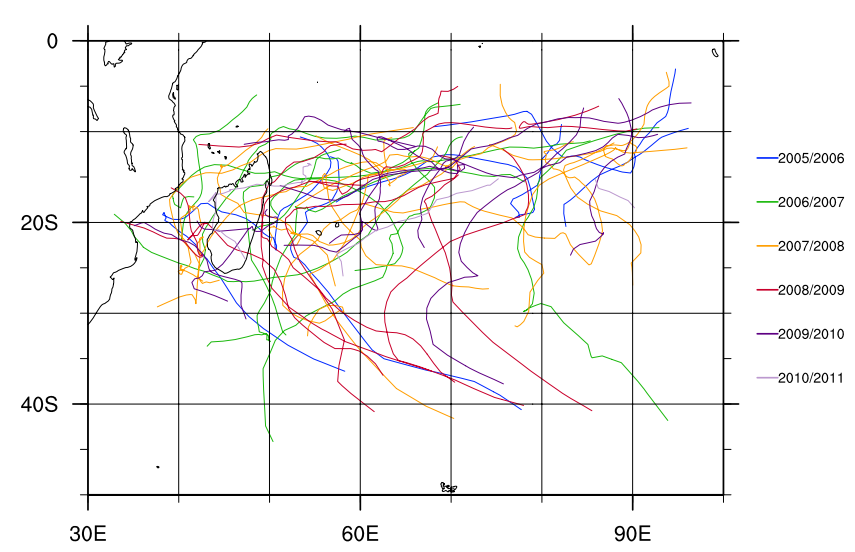

Fig. 2. Individual tracks of tropical storms from cyclonic seasons 2005/2006 to 2010/2011 in the SWIO. Source: RSMC La Réunion.

best-track database. The tracks of the 51 tropical storms and cyclones that developed in the basin between cyclonic seasons 2005/2006 and 2010/2011 are represented in Fig. 2. Lightning strokes associated with tropical storms are obtained as follows: the latitude and longitude of the storm center are linearly interpolated to the time of the lightning strike (from the WWLLN database) to calculate the distance between the storm center and the strike location. Only lightning flashes within a $600-\mathrm{km}$ radius from the storm center are considered to be part of the system. Indeed, according to the Joint Typhoon Warning Center, the average size of a TC is about 300 -to- $600 \mathrm{~km}$.

Figure 3a shows the cumulative flash density generated by TSs and TCs between cyclonic seasons 2005/2006 and 2010/2011. Lightning activity associated with TSs and TCs is mainly gathered south of $7^{\circ} \mathrm{S}$, in a triangular area defined by these points: $10^{\circ} \mathrm{S}, 40^{\circ} \mathrm{E} ; 10^{\circ} \mathrm{S}, 95^{\circ} \mathrm{E}$; and $30^{\circ} \mathrm{S}$, $45^{\circ} \mathrm{E}$. These systems produce a large amount of lightning flashes between $10^{\circ} \mathrm{S}$ and $20^{\circ} \mathrm{S}$. Two main regions with high flash densities $\left(>10 \mathrm{fl} \mathrm{km}^{-2}\right.$ ) appear: north-east of the Mascarene archipelago and in the northern part of the Mozambique channel. However, since the Mozambique channel and Madagascar are regions with high lightning activity, lightning flashes associated with TSs and TCs represent less than $10 \%$ of the total lightning activity over Madagascar and Africa, and range between 10 and $30 \%$ in the Mozambique channel (Fig. 3b). On the contrary, over the oceanic region between $10^{\circ} \mathrm{S}$ and $20^{\circ} \mathrm{S}$ and between $55^{\circ} \mathrm{E}$ and $90^{\circ} \mathrm{E}$, the proportion of lightning flashes associated with TSs and TCs can exceed $80 \%$ of the total lightning activity. Thus, lightning strokes associated with TSs and TCs represent the major source of lightning activity over some oceanic regions of the SWIO.
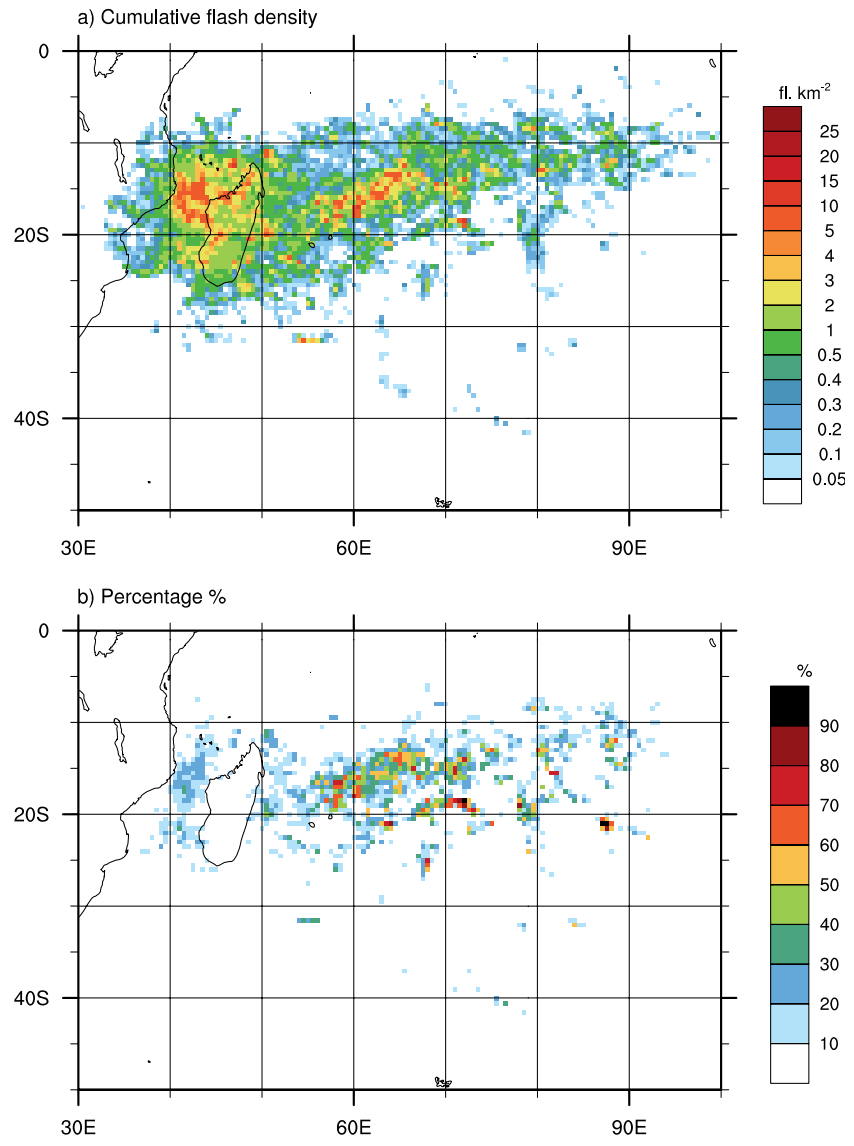

Fig. 3. Impact of tropical storms on the global lightning activity in the SWIO between cyclonic seasons 2005/2006 and 2010/2011. (a) Cumulative flash density $\left(\mathrm{fl} \mathrm{km}^{-2}\right.$ ) associated with TSs, and (b) contribution (\%) of lightning generated by TSs.

\subsection{Seasonal variation}

The SWIO is characterized by two seasons: the wet season is November to April, and the dry season is May to October. In order to study more precisely the evolution of lightning activity over the whole year, each 6-month period in splitted into two subsets (NDJ for November-December-January, FMA for February-March-April and MJJ for May-JuneJuly, ASO for August-September-October).

Figure 4 represents the trimestrial distribution of the mean flash density over the SWIO superimposed with Outgoing Longwave Radiation (OLR) contours. The OLR data are monthly $2.5^{\circ} \times 2.5^{\circ}$ gridded NOAA/ESRL/PSD (National Oceanic and Atmospheric Administration/Earth System Research Laboratory/Physical Sciences Division) (Liebmann and Smith, 1996) data and cover the same period as the WWLLN data (from January 2005 to December 2011). They have been averaged to get a trimestrial climatology. 

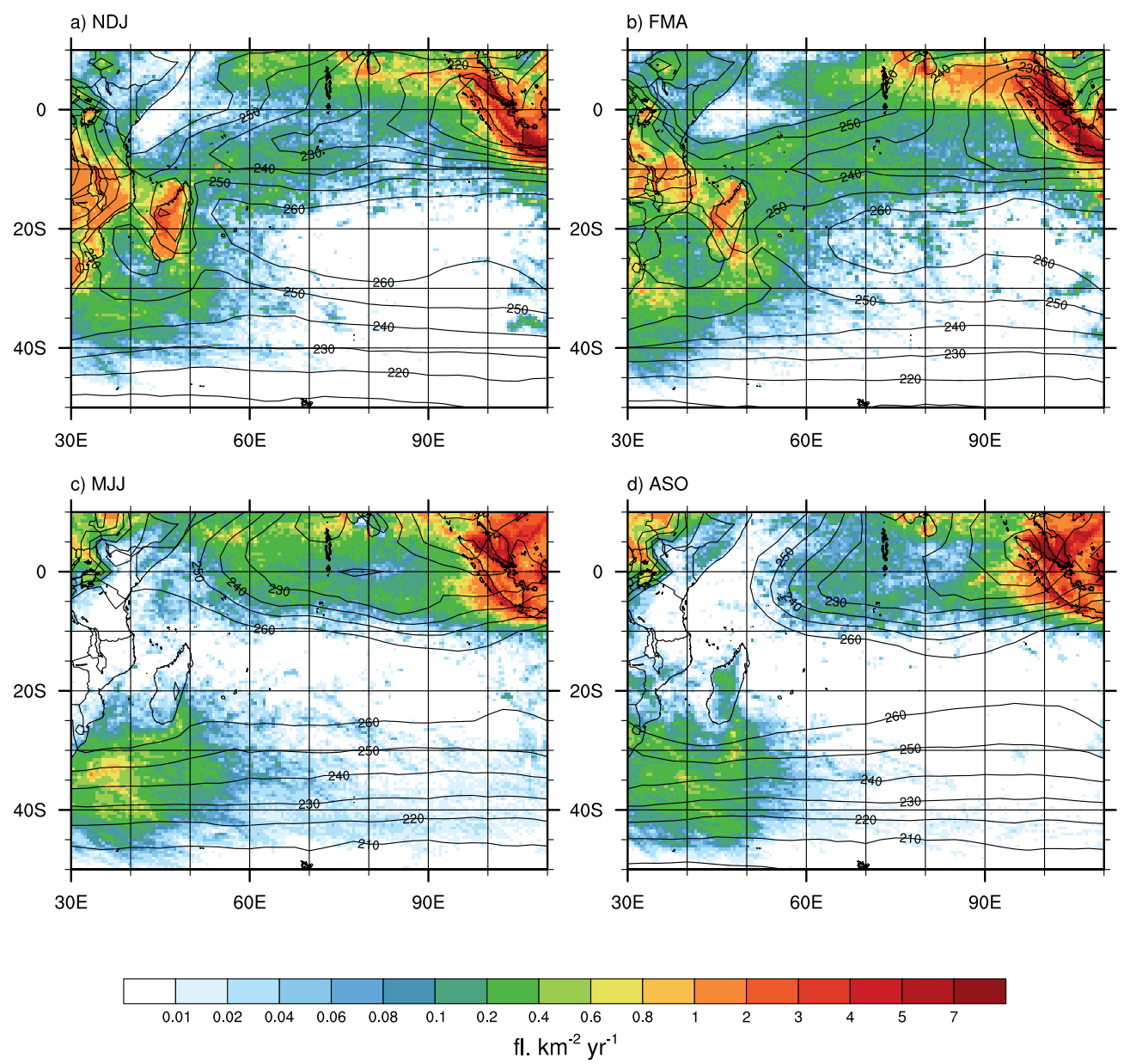

Fig. 4. The trimestrial distribution of lightning activity $\left(\mathrm{fl} \mathrm{km}^{-2} \mathrm{yr}^{-1}\right.$ ) for the period 2005-2011: (a) November, December and January, (b) February, March and April, (c) May, June and July and (d) August, September and October. Contours correspond to OLR values (W m ${ }^{-2}$ ).

\subsubsection{Wet season}

The maximum lightning activity in the SWIO is found during the wet season (Fig. 4a-b). Flash densities are higher over land (African continent and Madagascar) with values $>1 \mathrm{fl} \mathrm{km}{ }^{-2} \mathrm{yr}^{-1}$. A band of moderate flash density (0.1$0.6 \mathrm{fl} \mathrm{km}^{-2} \mathrm{yr}^{-1}$ ) extends trough an important oceanic part of the basin, between $0^{\circ} \mathrm{S}$ and $25^{\circ} \mathrm{S}$. These features are co-located with low values of OLR $\left(<240 \mathrm{~W} \mathrm{~m}^{-2}\right)$ used to define the ITCZ. Oceanic lightning strokes tend to occur in these regions of intense convection (OLR contours $<250 \mathrm{~W} \mathrm{~m}^{-2}$ on Fig. 4). Collier and Hughes (2011) concluded from their study that lightning in the tropics would not be a good locator of the ITCZ, as lightning activity over Africa tends to occur south of the ITCZ. However, they analyzed lightning activity in relation with the ITCZ position only over continental Africa. The dynamics of the ITCZ over land and ocean are not dictated by the same processes, which could explain the different results.
The Near Equatorial Trough (NET) (Sikka and Gadgil, 1980 ) is a secondary trough present above the Indian Ocean during the whole year and defined as an area of equatorial westerly winds near $3^{\circ} \mathrm{N}$ in January and near $3^{\circ} \mathrm{S}$ in July. Lightning activity reaches $1 \mathrm{f} \mathrm{km}^{-2} \mathrm{yr}^{-1}$ north of the equator during the wet season, in agreement with the NET location (Fig. 4a-b).

During NDJ (Fig. 4a), peaks of lightning activity are mainly found above land, $3-4 \mathrm{fl} \mathrm{km}^{-2} \mathrm{yr}^{-1}$ in Madagascar and $>1-2 \mathrm{fl} \mathrm{km}^{-2} \mathrm{yr}^{-1}$ over the African continent. During these months, the most active phase of the East Africa monsoon takes place over East Africa and Madagascar (Verschuren et al., 2009). In this configuration, the western part of Madagascar is influenced by northwest winds which bring moist air (evaporation from hot Indian Ocean). Convergence with the southeast trade winds results in increased instability. Moreover, under some conditions, monsoon depressions can develop and affect the western part of the SWIO (Baray et al., 2010). 
During the second part of the wet season (FMA), lightning activity tends to weaken over land. Indeed, flash density reaches up to $3 \mathrm{fl} \mathrm{km}^{-2} \mathrm{yr}^{-1}$ in the western part of Madagascar and up to $2 \mathrm{fl} \mathrm{km}^{-2} \mathrm{yr}^{-1}$ on the African continent (in Tanzania, Malawi, Zambia and Mozambique). However, over ocean near $10^{\circ} \mathrm{S}$, a straight band of moderate flash density (between 0.1 and $0.6 \mathrm{fl} \mathrm{km}^{-2} \mathrm{yr}^{-1}$ ) takes place, and it may be associated with the increase of SST (which mainly controls the position of the ITCZ over ocean). The number of lightning strokes in this same area seems to be greater than during NDJ. Two areas south-east of Madagascar and south-east of Africa exhibit an increase in lightning activity (between 0.6 and $2 \mathrm{fl} \mathrm{km}^{-2} \mathrm{yr}^{-1}$ ).

\subsubsection{Dry season}

The dry season is characterized by a low lightning activity in the central part of the SWIO (Fig. 4c-d). On the African continent, lightning activity is preferentially found north of the equator. A large area of lightning activity is present over ocean, east of South Africa and Madagascar. The ITCZ has moved northward and the NET is visible near $5^{\circ} \mathrm{S}$.

During the MJJ period (Fig. 4c), lightning strokes are quite rare between $10^{\circ} \mathrm{S}$ and $25^{\circ} \mathrm{S}$. As the Mascarene anticyclone moves westward, the altitude of the trade inversion lowers resulting in shallow convection. This high is climatologically located near $60^{\circ} \mathrm{E}$ in July (austral winter) and moves to $90^{\circ} \mathrm{E}$ in January (austral summer). Moreover, MJJ corresponds to the first 3 months of the winter season in the SWIO, so the thermal contrast (over land or ocean) is less pronounced leading to less intense convection. Lightning activity in the basin is concentrated over ocean east of Africa's shores and south of Madagascar. This feature is also visible in Christian et al. (2003), and also takes place south-east of Australia and South America. The year-round persistent presence of anticyclones (southern Atlantic, Indian Ocean and Australia) and the land-sea contrast in the Southern Hemisphere promote thunderstorm activity which extends eastward, up to thousands of kilometers from the coasts (Barnes and Newton, 1982).

During the ASO period (Fig. 4d), lightning activity tends to restart over land (Mozambique and Madagascar) even if the flash density remains moderate (up to $0.8 \mathrm{fl} \mathrm{km}^{-2} \mathrm{yr}^{-1}$ over South Africa). Compared to the previous period (MJJ), the ASO has a more sustained lightning activity over land while lightning activity over ocean erodes more and more. There is nearly no flash east of $70^{\circ} \mathrm{E}$ and flash density over ocean east of South Africa is less important than in MJJ.

\subsection{Modes of variability}

\subsubsection{High frequency modes}

Trend-Run has been used on high-pass band filtered time series to focus on modes with temporal periods between 1 and
5 months (to avoid the effects of the SAC). One unexpected result is that the MJO does not have an important contribution in the lightning activity modulation. Indeed, Abatzoglou and Brown (2009) showed that MJO affects the lightning activity over the continental United States. MJO causes the amplification of the upper-level ridge over the western US and the development of mid-tropospheric instability leading to an enhancement of lightning activity. Recently, Virts et al. (2011) studied the relationships between lightning and $\mathrm{NO}_{2}$ over the Maritime Continent using WWLLN data. They concluded that up to $\sim 50 \%$ of the observed variations can be attributed to MJO.

In order to confirm or not confirm the results obtained with Trend-Run, Fast Fourier Transforms (FFTs) have been performed on the same time series. Results (not presented here) show peaks at 2.5-3 months, which seems to be asociated with the MJO (period of 30-90 days). Trend-Run was then not able to reproduce the results given by the FFTs for the high frequency modes. Trend-Run is a linear regression fitting model. Then, if the relationship between lightning activity and MJO is non-linear, Trend-Run should not be able to emphasize it.

Recently, during the DYNAMO (DYNAmics of the Madden-Julian Oscillation; http://www.eol.ucar.edu/ projects/dynamo/) campaign, and for the area $7^{\circ} \mathrm{N}-$ $11^{\circ} \mathrm{S}, 65^{\circ} \mathrm{E}-83^{\circ} \mathrm{E}$, observations have shown that lightning activity seemed to be not affected by the MJO in this region. The MJO variance $\left(\mathrm{RMM}^{2}+\mathrm{RMM}^{2}\right.$; see Wheeler and Hendon, 2004) is extracted from http://cawcr.gov.au/staff/mwheeler/maproom/RMM/. Figure 5 illustrates the daily evolution of lightning activity superimposed with the time series of MJO variance for the DYNAMO area. The three MJO events (18 October 2011, 28 November 2011 and 23 December 2011) were clearly not associated with enhanced lightning activity.

\subsubsection{Low frequency modes}

Figure 6 summarizes the results obtained with Trend-Run for the low frequency modes (temporal period higher than 12 months). The highest coefficient of determination $\left(R^{2}=\right.$ 0.77 ) is located in the region $0^{\circ}-10^{\circ} \mathrm{S}, 60^{\circ} \mathrm{E}-70^{\circ} \mathrm{E}$. In this region, the lightning activity variability is mainly dominated by the IOD, contributing to $49 \%( \pm 11.8)$ of the signal. ENSO explains $18.1 \%( \pm 12.4)$ of the signal variation and the QBO $9.5 \%( \pm 8.6)$. Near the Maritime Continent $\left(0^{\circ}-\right.$ $\left.10^{\circ} \mathrm{S}, 90^{\circ} \mathrm{E}-100^{\circ} \mathrm{E}\right)$, the coefficient of determination is also high $\left(R^{2}=0.72\right)$ and, as expected, ENSO dominates the signal with a contribution of $42.3 \%( \pm 27.2)$. Most of the regions have correlations greater than 0.50 , which confirms that the modes defined in Trend-Run can globally explain the variations of the signals.

The inter-annual variations of lightning activity in the SWIO are mostly driven by the ENSO. It is the main forcing in 12 regions (on 21), with values ranging from $24.7 \%$ 


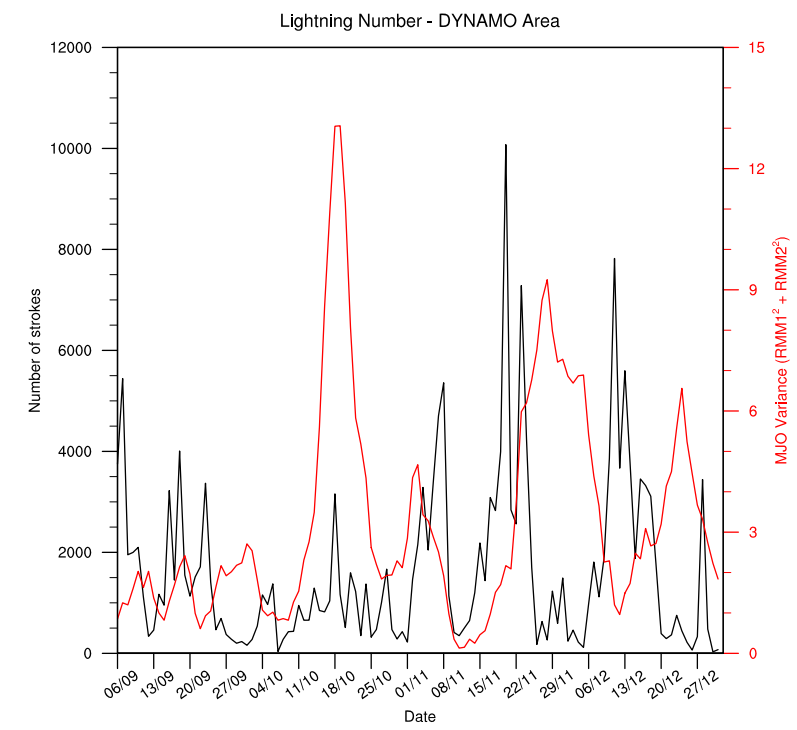

Fig. 5. Daily number of strokes from WWLLN (black) and MJO variance (red) for the period 6 September 2011 to 31 December 2011 and for the region $7^{\circ} \mathrm{N}-11^{\circ} \mathrm{S}, 65^{\circ} \mathrm{E}-83^{\circ} \mathrm{E}$.

$( \pm 12.3)$ to $56.8 \%( \pm 24.7)$ (Fig. 6). Lightning activity in the areas $20^{\circ} \mathrm{S}-30^{\circ} \mathrm{S}, 50^{\circ} \mathrm{E}-60^{\circ} \mathrm{E}$ and $20^{\circ} \mathrm{S}-30^{\circ} \mathrm{S}, 60^{\circ} \mathrm{E}-$ $70^{\circ} \mathrm{E}$ is modulated at $56.8 \%( \pm 24.7)$ and $52.9 \%( \pm 22.8)$, respectively, by this forcing. Previous studies have shown the positive correlations between ENSO and lightning activity at global scale (Durden et al., 2004; Chronis et al., 2008; Wu et al., 2012) and at lower scale (Goodman et al., 2000, over the Southwestern United States; Hamid et al., 2001, over Indonesia; and Yoshida et al., 2007, in the Southeast Asia and western Pacific).

The IOD plays an important role in 4 regions, especially in the $0^{\circ}-10^{\circ} \mathrm{S}$ region where its contribution reaches $49 \%$ $( \pm 11.8)$ (Fig. 6). Lightning activity in the southern part of Madagascar is affected by the IOD up to $39.9 \%( \pm 25.4)$.

The QBO has a greater influence in the eastern part of the domain but its contribution $(22.8 \%( \pm 15.4)$ and $16.7 \%$ $( \pm 13)$, second row; Fig. 6) is still smaller than the IOD and ENSO. Seasonal modulation of lightning activity by the QBO was investigated by Hernandez (2008) for different regions (Africa, India, Indonesia/Australia and South America). The QBO was decomposed into zonally symmetric westerly (west phase) and easterly (east phase) wind regimes. Results showed a different behavior depending on the phase and the geographic region.

\subsubsection{Discussion}

In some parts of the domain $\left(20^{\circ} \mathrm{S}-30^{\circ} \mathrm{S}, 80^{\circ} \mathrm{E}-100^{\circ} \mathrm{E}\right.$ Mascarene high and the $70^{\circ} \mathrm{E}-80^{\circ} \mathrm{E}$ belt), the forcings defined above can not explain the lightning variability. These modes of variability are probably not the main responsible cause of changes in lightning activity. The Trend-Run model only takes into account a limited number of forcings. Other phenomena like the Tropospheric Biennal Oscillation (Meehl et al., 2003) or convectively coupled equatorial waves (Kiladis et al., 2009) can enhance or dampen convection.

Another explanation is that lightning activity in the tropics is more dependent on dynamic forcing. It is assumed that important vertical velocities are required to carry relative humidity in altitude (generation of supercooled liquid water) and to separate charges thanks to the noninductive charging process (Reynolds et al., 1957; Williams and Lhermitte, 1983; Dye et al., 1989; Rutledge et al., 1992; Carey and Rutledge, 1996; Petersen et al., 1999; Latham et al., 2007). In the tropics, the troposphere has high value of relative humidity. When convection is triggered, the buoyancy term is not very important, leading to weak updrafts (Jorgensen and LeMone, 1989). Even if convection is enhanced by the MJO, ENSO or IOD, it does not mean that updrafts will be vigorous enough to generate supercooled liquid water and graupel, and then separate charges (Zipser and Lutz, 1994).

\section{Summary and conclusions}

Lightning activity over the South-West Indian Ocean has been explored. The dataset is composed by lightning flash records from the WWLLN from 2005 to 2011. A climatology in this region has been performed and is in agreement with the previous global study by Christian et al. (2003). The area of maximum lightning activity is the Maritime Continent (Java island) and the southwest of Sri Lanka with more than $50 \mathrm{fl} \mathrm{km}^{-2} \mathrm{yr}^{-1}$. Madagascar also exhibits high flash density (up to $20 \mathrm{fl} \mathrm{km}^{-2} \mathrm{yr}^{-1}$ ). In some oceanic areas, between $10^{\circ} \mathrm{S}$ and $20^{\circ} \mathrm{S}$, TSs and TCs are the major source of lightning activity (ranging from $50 \%$ to $100 \%$ ).

The austral summer is the most electrically active period in the SWIO as the ITCZ is present all over the basin and the northern part of the domain is influenced by the NET. During the winter season, as the Mascarene high moves northward, convection (and consequently lightning activity) is inhibited due to the presence of the trade inversion.

Lightning activity in the SWIO was found to be mainly modulated by ENSO (up to $56.8 \%$ ). The IOD forcing is significant in some regions (up to $\sim 49 \%$ in the northern central Indian Ocean). Inter-annual variability has a greater impact than intra-annual variability. It was expected that the MJO would play an important role in the modulation of lightning activity, but high frequency modes did not show significant results using Trend-Run model. However, we obtained the opposite results suggesting that the modulation of lightning activity by the MJO is quite complex and needs to be studied more precisely.

This study has shown some limitations, in particular concerning the WWLLN DE and the modes of variability. First of all, the WWLLN DE is quite low, which constrained us to scale up the data to obtain significative values. Secondly, 

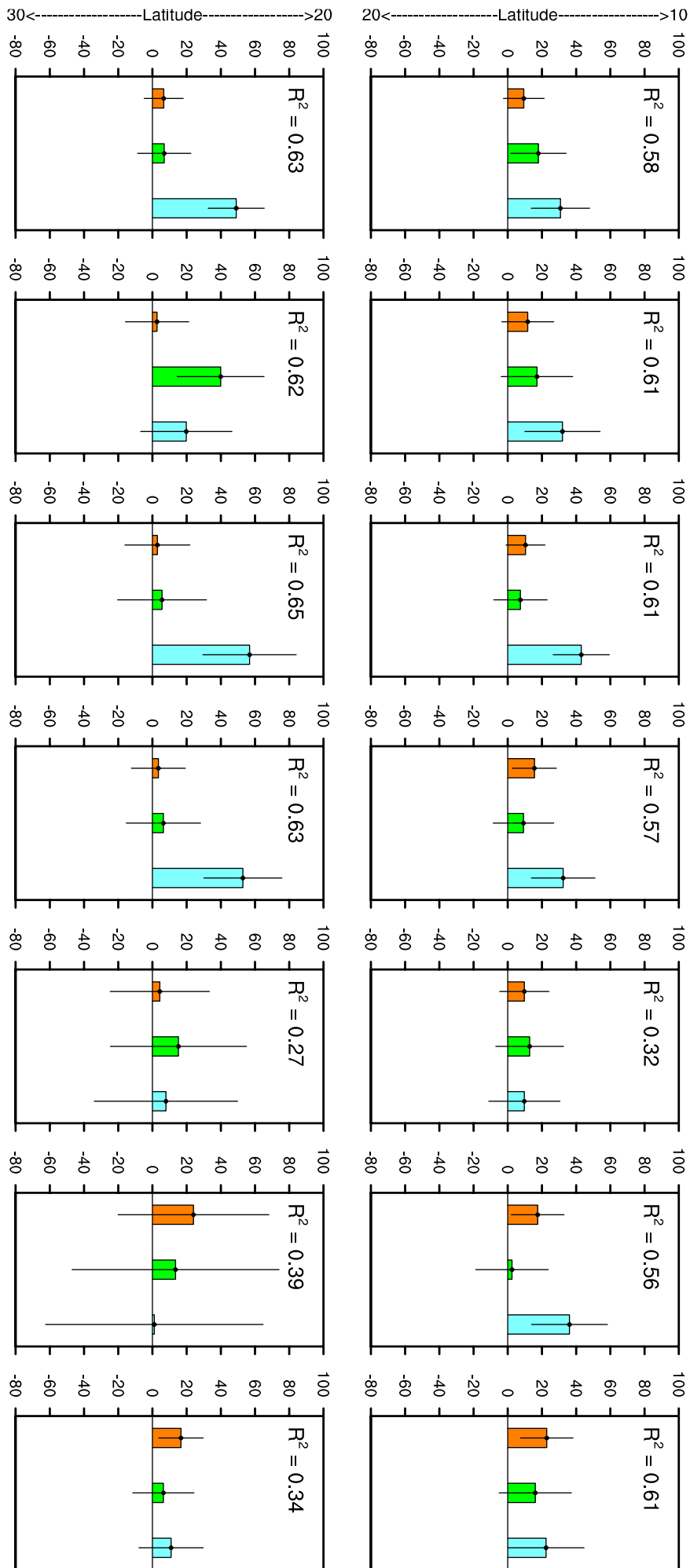
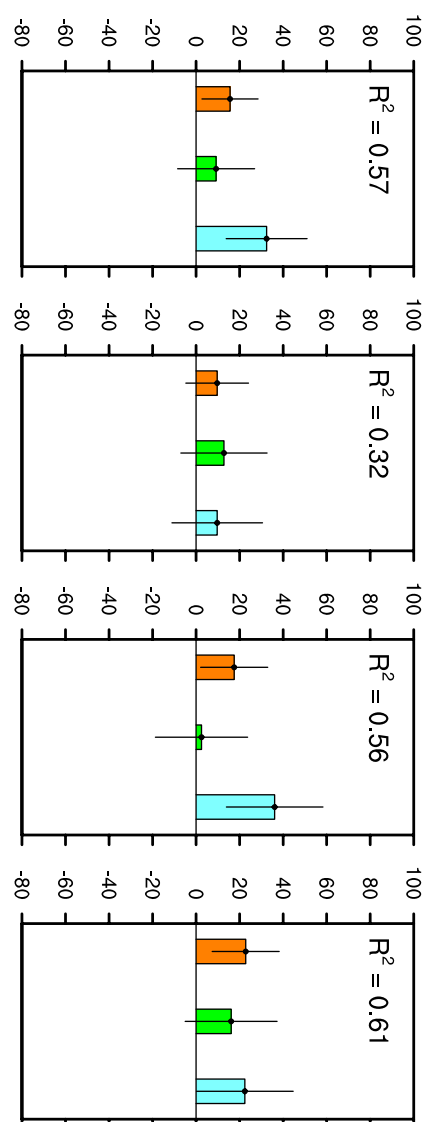

$10<----------------L a t i t u d e--------------->0$

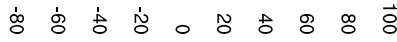
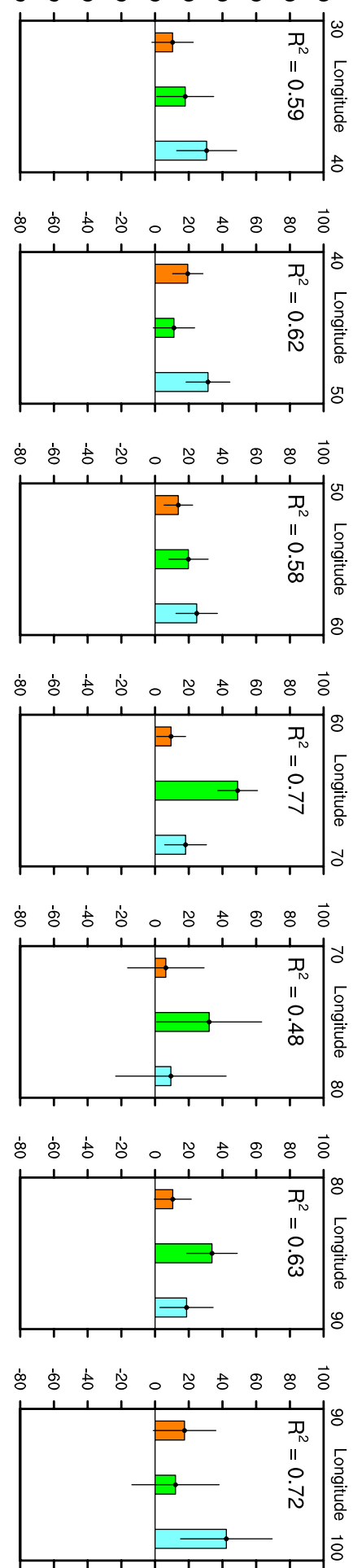

Fig. 6. Contributions (color boxes, in \%) and standard deviations (black segments, in \%) of the different forcings per $10^{\circ} \times 10^{\circ}$ bin. Orange, green and blue bars represent the QBO, the IOD and the ENSO, respectively. The coefficients of determination $\left(R^{2}\right)$ are indicated on the top of each box. 
the length of the dataset provided by the WWLLN is still too short to provide strong relationships between lightning activity and modes of variability.

However, the similarity between the different climatologies (global or regional) have confirmed the reliability of the WWLLN data. The present paper has highlighted that lightning activity within TSs and TCs is significant and needs to be more precisely studied. Moreover, this work can be helpful in determining regions and periods to observe TLEs in the SWIO.

Acknowledgements. This work was financially supported by La Région Réunion and the European Union, and by the Fondation MAIF through the PRECYP project. The authors wish to thank the World Wide Lightning Location Network (http://www.wwlln.net/), a collaboration among 40 universities and institutions, for providing the lightning location used in this study.

Edited by: A. Mugnai

Reviewed by: A. B. Collier and one anonymous referee

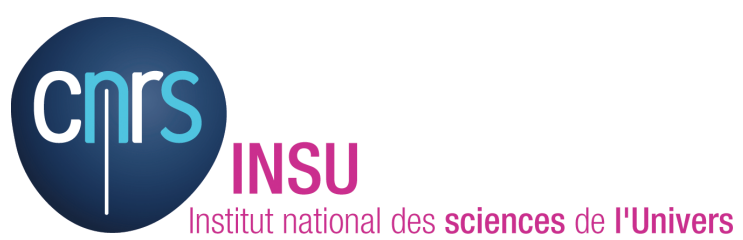

The publication of this article is financed by CNRS-INSU.

\section{References}

Abarca, S. F., Corbosiero, K. L., and Galarneau Jr., T. J.: An evaluation of the World Wide Lightning Location Network (WWLLN) using the National Lightning Detection Network (NLDN) as ground truth, J. Geophys. Res., 115, D18206, doi:10.1029/2009JD013411, 2010.

Abarca, S. F., Corbosiero, K. L., and Vollaro, D.: The World Wide Lightning Location Network and convective activity in tropical cyclones, Mon. Weather Rev., 139, 175-191, 2011.

Abatzoglou, J. T. and Brown, T. J.: Influence of the Madden-Julian Oscillation on summertime cloud-to-ground lightning activity over the continental United States, Mon. Weather Rev., 137, 3596-3601, 2009.

Alexander, M. A., Bladé, I., Newman, M., Lanzante, J. R., Lau, N.-C., and Scott, J. D.: The atmospheric bridge: The influence of ENSO teleconnections on air-sea interaction over the global oceans, J. Climate, 15, 2205-2231, 2002.

Antonescu, B. and Burcea, S.: A cloud-to-ground lightning climatology for Romania, Mon. Weather Rev., 138, 579-591, 2010.

Baray, J.-L., Clain, G., Plu, M., Feld, E., and Caroff, P.: Occurrence of monsoon depressions in the southwest Indian Ocean: Synoptic descriptions and stratosphere to troposphere exchange investigations, J. Geophys. Res., 115, D17108, doi:10.1029/2006JD007484, 2010.

Barnes, S. L. and Newton, C. W.: in: Thunderstorms: A Social, Scientific, and Technological Documentary, Vol. 2, Thunderstorm
Morphology and Dynamics, edited by: Kessler, E., chap. Thunderstorms in the synoptic setting, US Dept. of Commerc., Washington, DC, 109-171, 1982.

Bègue, N., Bencherif, H., Sivakumar, V., Kirgis, G., Mze, N., and Leclair de Bellevue, J.: Temperature variability and trends in the UT-LS over a subtropical site: Reunion $\left(20.8^{\circ} \mathrm{S}, 55.5^{\circ} \mathrm{E}\right)$, Atmos. Chem. Phys., 10, 8563-8574, doi:10.5194/acp-10-85632010, 2010.

Behera, S. K. and Yamagata, T.: Influence of the Indian Ocean Dipole on the Southern Oscillation, J. Meteorol. Soc. Jpn, 81, 169-177, 2003.

Beirle, S., Huntrieser, H., and Wagner, T.: Direct satellite observation of lightning-produced $\mathrm{NO}_{\mathrm{x}}$, Atmos. Chem. Phys., 10, 10965-10986, doi:10.5194/acp-10-10965-2010, 2010.

Bencherif, H., Diab, R. D., Portafaix, T., Morel, B., Keckhut, P., and Moorgawa, A.: Temperature climatology and trend estimates in the UTLS region as observed over a southern subtropical site, Durban, South Africa, Atmos. Chem. Phys., 6, 5121-5128, doi:10.5194/acp-6-5121-2006, 2006.

Black, R. A. and Hallet, J.: Electrification of the hurricane, J. Atmos. Sci., 56, 2004-2028, 1999.

Boccippio, D. J., Koshak, W. J., and Blakeslee, R. J.: Performance assessment of the Optical Transient Detector and Lightning Imaging Sensor, Part I: Predicted diurnal variability, J. Atmos. Ocean. Technol., 19, 1318-1332, 2002.

Bucsela, E. J. et al.: Lightning-generated $\mathrm{NO}_{\mathrm{x}}$ seen by the Ozone Monitoring Instrument during NASA's Tropical Composition, Cloud and Climate Coupling Experiment $\left(\mathrm{TC}^{4}\right)$, J. Geophys. Res., 115, D00J10, doi:10.1029/2009JD013118, 2001.

Carey, L. D. and Rutledge, S. A.: A multiparameter radar case study of the microphysical and kinematic evolution of a lightning producing storm, Meteorol. Atmos. Phys., 59, 33-64, 1996.

Caroff, P., Bientz, C., ans T. Dupont, O. C., Charlat, A., and Fontan, A.-C.: Cyclone season of south-west Indian Ocean 2006-2007, Météo France - Direction Interrégionale de La Réunion, SainteClotilde, La Réunion, France, 2008.

Christian, H. J., Blakeslee, R. J., Boccippio, D. J., Boeck, W. L., Buechler, D. E., Driscoll, K. T., Goodman, S. J., Hall, J. M., Koshak, W. J., Mach, D. M., and Stewart, M. F.: Global frequency and distribution of lightning as observed from space by the Optical Transient Detector, J. Geophys. Res., 108, 4005, doi:10.1029/2002JD002347, 2003.

Chronis, T. G., Goodman, S. J., Cecil, D., Buechler, D., Robertson, F. J., Pittman, J., and Blakeslee, R. J.: Global lightning activity from the ENSO perspective, Geophys. Res. Lett., 35, L19804, doi:10.1029/2008GL034321, 2008.

Collier, A. B. and Hughes, A. R. W.: Lightning and the African ITCZ, J. Atmos. Solar-Terr. Phys., 73, 2392-2398, 2011.

Collier, A. B., Hughes, A. R. W., Lichtenberger, J., and Steinbach, P.: Seasonal and diurnal variation of lightning activity over southern Africa and correlation with European whistler observations, Ann. Geophys., 24, 529-542, doi:10.5194/angeo-24-529-2006, 2006.

Collimore, C., Martin, D. W., Hitchman, M. H., Huesmann, A., and Waliser, D. E.: On the relationship between the QBO and tropical deep convection, J. Climate, 16, 2552-2568, 2003.

DeMaria, M., DeMaria, R. T., Knaff, J. A., and Molenar, D.: Tropical cyclone lightning and rapid intensity change, Mon. Weather Rev., 140, 1828-1842, doi:10.1175/MWR-D-11-00236.1, 2012. 
Durden, S. L., Meagher, J. P., and Haddad, Z. S.: Satellite observations of spatial and interannual variability of lightning and radar reflectivity, Geophys. Res. Lett., 31, L18111, doi:10.1029/2004GL020384, 2004.

Dye, J. E., Winn, W. P., Jones, J. J., and Breed, D. W.: The electrification of New Mexico thunderstorms 1. Relationship between precipitation development and the onset of electrification, J. Geophys. Res., 94, 8643-8656, 1989.

Fierro, A. O., Shao, X.-M., Hamlin, T., Reisner, J. M., and Harlin, J.: Evolution of eyewall convective events as indicated by intracloud and cloud-to-ground lightning activity during the rapid intensification of hurricanes Rita and Katrina, Mon. Weather Rev., 139, 1492-1504, 2011.

Fujita, M., Kimura, F., and Yoshizaki, M.: Morning precipitation peak over the Strait of Malacca under a calm condition, Mon. Weather Rev., 138, 1474-1486, 2010.

Goodman, S. J., Buechler, D. E., Knupp, K., Driscoll, K., and McCaul Jr, E. W.: The 1997-98 El Niño Event and related wintertime lightning variations in the southeastern United States, Geophys. Res. Lett., 27, 541-544, 2000.

Hamid, E. Y., Kawasaki, Z.-I., and Mardiana, R.: Impact of the 1997-98 El Niño event on lightning activity over Indonesia, Geophys. Res. Lett., 28, 147-150, 2001.

Hernandez, C. A.: The Quasi-Biennal Oscillation's influence on lightning production and deep convection in the tropics, Master's thesis, Texas A\&M University, 2008.

Hodanish, S., Sharp, D., Collins, W., Paxton, C., and Orville, R. E.: A 10-yr monthly lightning climatology of Florida: 1986-95, Weather Forecast., 12, 439-448, 1997.

Jorgensen, D. P. and LeMone, M. A.: Vertical velocity characteristics of oceanic convection, J. Atmos. Sci., 46, 621-640, 1989.

Kiladis, G. N., Wheeler, M. C., Haertel, P. T., Straub, K. H., and Roundy, P. E.: Convectively coupled equatorial waves, Rev. Geophys., 47, RG2003, doi:10.1029/2008RG000266, 2009.

Kucieńska, B., Raga, G. B., and Rodríguez, O.: Cloud-to-ground lightning over Mexico and adjacent oceanic regions: a preliminary climatology using the WWLLN dataset, Ann. Geophys., 28, 2047-2057, doi:10.5194/angeo-28-2047-2010, 2010.

Kuleshov, Y., Mackerras, D., and Darveniza, M.: Spatial distribution and frequency of lightning activity and lightning flash density maps for Australia, J. Geophys. Res., 111, D19105, doi:10.1029/2005JD006982, 2006.

Latham, J., Petersen, W. A., Deierling, W., and Christian, H. J.: Field identification of a unique globally dominant mechanism of thunderstorm electrification, Q. J. Roy. Meteor. Soc., 133, 14531457, 2007.

Lau, K.-M. and Yang, S.: Walker Circulation, in: Encyclopedia of Atmospheric Sciences, 2505-2510, doi:10.1016/B0-12-2270908/00450-4, 2003.

Liebmann, B. and Smith, C. A.: Description of a complete (interpolated) outgoing longwave radiation dataset, Bull. Am. Meteorol. Soc., 77, 1275-1277, 1996.

Meehl, G. A., Arblaster, J. M., and Loschnigg, J.: Coupled oceanatmosphere dynamical processes in the tropical Indian and $\mathrm{Pa}$ cific Oceans and the TBO, J. Climate, 16, 2138-2158, 2003.

Morioka, K., Tomoki, T., and Yamagata, T.: Climate variability in the southern Indian Ocean as revealed by self-organizing maps, Clim. Dynam., 35, 1059-1072, 2010.
Neumann, C.: Global guide to tropical cyclone forecasting, WMO Trop. Cyclone Program Rep. TCP-31, chap. Global Overview, World Meteorol. Organ., Geneva, Switzerland, 43 pp., 1993.

Petersen, W. A., Rutledge, S. A., Cifelli, R. C., Ferrier, B. S., and Smull, B. F.: Shipborn dual-Doppler operations during TOGA COARE: Integrated observations of storm kinematics and electrification, Bull. Am. Meteorol. Soc., 80, 81-97, 1999.

Price, C., Asfur, M., and Yair, Y.: Maximum hurricane intensity preceded by increase in lightning frequency, Nat. Geosci., 2, 329332, 2009.

Reap, R. M. and Orville, R. E.: The relationships between network lightning surface and hourly observations of thunderstorms, Mon. Weather Rev., 118, 94-108, 1990.

Reynolds, S. E., Brook, M., and Gourley, M. F.: Thunderstorm charge separation, J. Atmos. Sci., 14, 426-436, 1957.

Rivas Soriano, L., de Pablo, F., and Tomas, C.: Ten-year study of cloud-to-ground lightning activity in the Iberian Peninsula, J. Atmos. Sol. Terr. Phys., 67, 1632-1639, 2005.

Rodger, C. J., Brundell, J. B., Holzworth, R. H., and Lay, E. H.: Growing detection efficiency of the World Wide Lightning Location Network, in: Coupling of thunderstorms and lightning discharges to near-Earth space, Corte (France), 23-27 June 2008, 1118, 15-20, doi:10.1063/1.3137706, 2009.

Rutledge, S. A., Williams, E. R., and Keenan, T. D.: The Down Under Doppler and Electricity Experiment (DUNDEE): Overview and preliminary results, Bull. Am. Meteorol. Soc., 73, 3-16, 1992.

Saji, N. H., Goswami, B. N., Vinayachandran, P. N., and Yamagata, T.: Dipole mode in the tropical Indian Ocean, Nature, 401, 360363, 1999.

Schulz, W., Cummins, K., Diendorfer, G., and Dorninger, M.: Cloud-to-ground lightning in Austria: A 10-year study using data from a lightning location system, J. Geophys. Res., 110, D09101, doi:10.1029/2004JD005332, 2005.

Sikka, D. R. and Gadgil, S.: On the maximum cloud zone and the ITCZ over Indian longitudes during the southwest monsoon, Mon. Weather Rev., 108, 1840-1853, 1980.

Solorzano, N. S., Thomas, J. N., and Holzworth, R. H.: Global studies of tropical cyclones using the World Wide Lightning Location Network, in: Proceedings of the AMS 2008 meeting, New Orleans, LA, USA, 2008.

Soula, S., van der Velde, O., Montanya, J., Huet, P., Barthe, C., and Bór, J.: Gigantic jets produced by an isolated tropical thunderstorm near Réunion Island, J. Geophys. Res., 116, D19103, doi:10.1029/2010JD015581, 2011.

Squires, K. and Businger, S.: The morphology of eyewall lightning outbreak in two category 5 hurricanes, Mon. Weather Rev., 136, 1706-1726, 2008.

Teo, C.-K., Koh, T.-Y., Lo, J. C.-F., and Bhatt, B. C.: Principal component analysis of observed and modeled diurnal rainfall in the Maritime Continent, J. Climate, 24, 4662-4675, 2011.

Thomas, J. N., Solorzano, N. N., Cummer, S. A., and Holzworth, R. H.: Polarity and energetics of inner core lightning in three intense North Atlantic hurricanes, J. Geophys. Res., 115, A00E15, doi:10.1029/2009JA014777, 2010.

Timm, O., Pfeiffer, M., and Dullo, W.-C.: Nonstationary ENSOprecipitation teleconnection over the equatorial Indian Ocean documented in a coral from the Chagos Archipelago, Geophys. Res. Lett., 32, L02701, doi:10.1029/2004GL021738, 2005. 
Tourre, Y. M. and White, W. B.: Patterns of coherent climate signals in the Indian Ocean during the 20th century, Geophys. Res. Lett., 30, 2224, doi:10.1029/2003GL018476, 2003.

Verschuren, D., Sinninghe Damsté, J. S., Moernaut, J., Kristen, I., Blaauw, M., Fagot, M., Haug, G. H., and CHALLACEA project members: Half-precessional dynamics of monsoon rainfall near the East African equator, Nature, 462, 637641, doi:10.1038/nature08520, 2009.

Virts, K. S., Thornton, J. A., Wallace, J. M., Hutchins, M. L., Holzworth, R. H., and Jacobson, R. A.: Daily and intraseasonal relationships between lightning and $\mathrm{NO}_{2}$ over the Maritime Continent, Geophys. Res. Lett., 38, L19803, 2011.

Wescott, E. M., Sentman, D. D., Stenbæk-Nielsen, H. C., Huet, P., Heavner, M. J., and Moudry, D.: New evidence for the brightness of ionization of blue starters and blue jets, J. Geophys. Res., 106, A10, doi:10.1029/2000JA000429, 2001.

Wheeler, M. C. and Hendon, H. H.: An all-season real-time multivariate MJO index: Development of an index for monitoring and prediction, Mon. Weather Rev., 132, 1917-1932, 2004.

Williams, E. R. and Lhermitte, R. M.: Radar tests of the precipitation hypothesis for thuderstorm electrification, J. Geophys. Res., 88, 10984-10992, 1983.
Williams, E. and Stanfill, S.: The physical origin of the land-ocean contrast in lightning activity, C. R. Physique, 3, 1277-1292, doi:10.1016/S1631-0705(02)01407-X, 2002.

World Meteorological Organization: World distribution of thunderstorm days. Part 1: Tables, WMO Publ. 21, TP 6, Geneva, Switzerland, 1953.

Wu, Y. J., Chen, A. B., Hsu, H. H., Chou, J. K., Chang, S. C., Lee, L. J., Lee, Y. J., Su, H. T., Kuo, C. L., Hsu, R. R., Frey, H. U., Mende, S. B., Takahashi, Y., and Lee, L. C.: Occurence of elves and lightning during El Niño and La Niña, Geophys. Res. Lett., 39, L03106, doi:10.1029/2011GL04983, 2012.

Yoshida, S., Morimoto, T., Ushio, T., and Kawasaki, Z.: ENSO and convective activities in southeast Asia and western Pacific, Geophys. Res. Lett., 34, L21806, doi:10.1029/2007GL030758, 2007.

Zhang, C.: Large-scale variability of atmospheric deep convection in relation to sea surface temperature in the tropics, J. Climate, 6 , 1898-1913, 1993.

Zhang, C.: Madden-Julian Oscillation, Rev. Geophys., 43, RG2003, doi:10.1029/2004RG000158, 2005.

Zipser, E. J. and Lutz, K. R.: The vertical profile of radar reflectivity of convective cells: A strong indicator of storm intensity and lightning probability?, Mon. Weather Rev., 122, 1751-1759, 1994. 